\title{
Is Economic Growth Sustainable? Environmental Quality of I ndian States Post 1991
}

Sacchidananda Mukherjee

Research Scholar

and

Vinish Kathuria

Associate Professor

MADRAS SCHOOL OF ECONOMICS

Gandhi Mandapam Road

Chennai 600025

India

March 2006 


\section{Is Economic Growth Sustainable? Environmental Quality Of Indian States Post 1991}

\section{Sacchidananda Mukherjee*}

Research Scholar

and

Vinish Kathuria

Associate Professor

* Corresponding author

Tel.: +91-44-2235 2157; 2230 0304; 2230 0307; Cell: +91 9840699343

Fax: +91-44-2235 2155; 22354847

E-mail address: sachs.mse@gmail.com 
WORKING PAPER 6/2006

March 2006

Price : Rs.35
MADRAS SCHOOL OF ECONOMICS Gandhi Mandapam Road

\section{Chennai 600025}

\section{India}

Phone: 2230 0304/ 2230 0307/2235 2157

Fax : $22354847 / 22352155$

Email : info@mse.ac.in

Website: www.mse.ac.in 


\title{
IS ECONOMIC GROWTH SUSTAINABLE? ENVIRONMENTAL QUALITY OF INDIAN STATES POST 1991
}

\author{
Sacchidananda Mukherjee* \\ and \\ Vinish Kathuria
}

\begin{abstract}
This study is an attempt to investigate the relationship between environmental quality and per capita NSDP (i.e., Environment Kuznets Curve, EKC) of 14 major Indian States in the light of their very high economic growth in the post-liberalisation period. The analysis involves first ranking the States on the basis of their environmental quality, and then checking the relationship. The analysis captures both temporal and spatial aspects of environmental quality by ranking the States in two time periods - (i) early 1990s (1990 - 1996) and (ii) late 1990s (1997 - 2001). The results indicate that the relationship between environmental quality and per capita NSDP is slanting S-shaped. Except Bihar all other States are on the upward sloping curve of the EKC. The results suggest that the economic growth is mostly at the cost of environmental quality.
\end{abstract}

\section{* Acknowledgement}

We are grateful to Prof. Paul P. Appasamy, for his encouragement to take up this study. Our discussions with Prof. U. Sankar and Prof. Ramprasad Sengupta led to a substantial improvement in this paper. Earlier version of the paper has been presented at the International Conference on 'Environment and Development: Developing Countries Perspective' held in Jawaharlal Nehru University, New Delhi, April 7-8, 2005. We wish to thank the conference participants for their useful comments and observations. The usual disclaimers nevertheless apply. 


\title{
1. Introduction
}

The nineties have been watershed in the economic history of India, as the country embarked on liberalisation process in 1991. The liberalisation not only induced various States to enhance their production capacities but also facilitated restructuring of their economic activities. However, inter-State disparities in natural resources endowments have played a crucial role in this restructuring. Based on inter- and intra-sectoral differences in economic activities, different States have put different level of stress on their natural resources. The liberalisation process and emphasis to grow faster has resulted in on an average nearly 7-8 per cent growth rates of different States in the 1990s against 3-4 per cent average growth during the 1980s. ${ }^{1}$ However, in their pursuit to grow rapidly, most of the Indian States seem to have neglected key environmental and natural resources concerns, which in turn has resulted in large-scale depletion of natural resources and rapid degradation of the environment (see for example, Nadkarni, 2000; Kothari, 1996 among others for evidence).

For a country, having high dependence on natural resources, managing and protecting the environment is the key to ensure environmental and economic sustainability. In fact, this is also one of the Millennium Development Goals (MDGs) of the United Nations. ${ }^{2}$

\begin{abstract}
Economic growth plays a crucial role for socio-economic development. However, economic development and environmental sustainability are not supplementary to each other. Sustained development is elusive without sustainable environment, especially for developing countries
\end{abstract}

\footnotetext{
${ }^{1}$ Source: EPWRF (2003). See Table 7 of the paper for State-wise growth rate during the 1990s.

${ }^{2}$ It is to be noted that among 18 Targets of the MDGs, six (Targets 2, 5, 8, 9 and 10) are directly linked to sustainability and sustainable development issues (see http://www.developmentgoals.org/ for these goals).
} 
like India, Kenya where a large section of the society depends on natural resources for livelihood, directly or indirectly (Dasgupta, 2001). Unlike developed countries, developing countries do not have adequate financial resources to tackle the problem of natural resource depletion or degradation. Hence it is imperative that developing countries should protect their natural resources, rather than searching for solutions after depletion and degradation. The natural resource degradation, if not checked, will result in large-scale poverty and destitution, and can hamper the very process of socio-economic development of the populace (Agarwal, 1995 and Nadkarni, 2000).

Under this backdrop, the main objective of this study is to see - how the States have performed after economic liberalisation with respect to the protection of environmental quality? To investigate the issue, the study first captures inter-State variations in the environmental situations by ranking the States according to their environmental quality. Once the environmental status of different States is found, the study then tests whether economic development has any relationship with environmental quality or not?

The analysis is based on various secondary environmental information available for 14 major Indian States for the time period 1990 to 2001. In order to fathom the change in environmental quality due to liberalisation process, the period is bifurcated into two sub-periods - early 1990s (1990-1996) and late 1990s (1997-2001). For both the sub-periods, 63 environmental indicators have been clustered under 8 broad environmental groups. To rank the States under each group Principal Component Analysis (PCA) method of factor analysis has been used. The ranks obtained by an individual State across the different environmental criteria are then added using Borda Rule to get the final environmental 
quality (EQ) score. Finally, we compare the EQ scores of the States with their per capita Net State Domestic Product (PCNSDP) to verify the Environmental Kuznets Curve $(E K C)^{3}$ hypothesis using a multivariate regression analysis.

The analysis shows that for early 1990s, the better performing States with respect to environmental quality are Andhra Pradesh (AP), Orissa, Kerala and West Bengal (WB), and for the late 1990s are Madhya Pradesh (MP), Orissa, Bihar and Uttar Pradesh (UP). For both the subperiods, Haryana, Punjab, Gujarat, Karnataka are some of the poor performing States in terms of environmental quality. During the late 1990s, MP, Maharashtra, Bihar and UP have improved their rankings, whereas AP, WB and Tamilnadu (TN) have lost their earlier positions.

The relationship between economic development, measured by the PCNSDP at constant (1993-94) prices, and the EQ score shows non-linearity as predicted in EKC. Some of the States having low PCNSDP have better environmental quality, however other States like Maharashtra, Gujarat, TN, WB and Karnataka are on the upward sloping curve of the EKC and may continue to degrade environment if continue to grow at the same pace.

The remaining paper is organised as follows: Section 2 gives a brief literature review of environmental ranking at country level, followed by studies carried out to test Environmental Kuznets Curve (EKC) hypothesis. Section 3 gives methodology, data sources and description of the variables. Section 4 provides the results and analysis of environmental quality of different States, whereas Section 5 gives the results for EKC hypothesis. Paper concludes with Section 6.

\footnotetext{
${ }^{3}$ Environmental Kuznets Curve (EKC) originates from the works of Simon Kuznets. The original Kuznets curve show how income inequality changes as income in a country rises, wherever EKC shows how environmental quality change with change in income in a country.
} 


\section{Literature Review}

\subsection{Environmental Sustainability I ndex - A Review}

As a scientific tool to measure environmental performance across the geographical area, ranking on the basis of construction of environmental index has always been an important area of research both for individual researchers (see for example, Rogers et al., 1997; Adriaanse et al., 1995; Adriaanse, 1993 among others) and various development agencies (WWF, 2002; CBD/UNEP, undated; The Fraser Institute by Jones et al., 2002; RIVM/UNEP, undated).

Most of these studies, especially by the multilateral agencies, compute the index on yearly basis, which has significant developmental and environmental policy implications. However these studies differ considerably in their scope, coverage area, methodology and in the selection of variables for the construction of an index. ${ }^{4}$

The most recent index of environmental sustainability has been constructed by Esty et al. (2005) for 146 countries. The main objective of the study is to provide a composite profile of national environmental stewardship in the protection of environment over the next several decades. It is based on a compilation of 21 indicators that derive information from 76 underlying data sets covering all aspects of environment. ${ }^{5}$

Table 1 gives the details of the scores and ranks obtained by the South Asian countries in the 2005 Environmental Sustainability Index (ESI). It shows that India's position is $101^{\text {st }}$, whereas other South Asian countries like Bhutan, Sri Lanka and Nepal are far ahead in terms of Environmental Sustainability.

\footnotetext{
${ }^{4}$ For more details see http://farmweb.jrc.cec.eu.int/ci/Indexes.htm.

${ }^{5}$ See Esty et al. (2005) for details about these indicators.
} 
Table 1: 2005 Environmental Sustainability Index - Scores and Rankings

\begin{tabular}{|l|c|c|c|c|c|}
\hline $\begin{array}{c}\text { Country } \\
\text { Name }\end{array}$ & $\begin{array}{c}\text { ESI } \\
\text { Score }\end{array}$ & $\begin{array}{c}\text { ESI } \\
\text { Rank }\end{array}$ & $\begin{array}{c}\text { SAARC* } \\
\text { Rank\# }\end{array}$ & $\begin{array}{c}\text { Per Capita Gross } \\
\text { National Income } \\
\text { (in US \$) 2004 }\end{array}$ & $\begin{array}{c}\text { Per Capita } \\
\text { GNI (in US } \\
\text { \$) Ranks } \\
\text { (6) }\end{array}$ \\
\hline Bhutan & 53.5 & 43 & 1 & 670 & 5 \\
\hline Sri Lanka & 48.5 & 79 & 2 & 1010 & 6 \\
\hline Nepal & 47.7 & 85 & 3 & 260 & 1 \\
\hline India & $\mathbf{4 5 . 2}$ & $\mathbf{1 0 1}$ & $\mathbf{4}$ & $\mathbf{6 2 0}$ & 4 \\
\hline Bangladesh & 44.1 & 114 & 5 & 430 & 2 \\
\hline Pakistan & 39.9 & 131 & 6 & 600 & 3 \\
\hline
\end{tabular}

Source: Compiled from Esty et al. (2005) and World Development Indicator (2004) Notes: * - SAARC: South Asian Association for Regional Cooperation; Among 146 countries, Finland stood first with ESI score of 75.1 and North Korea came last with 29.2; \# - Maldives, a SAARC member was not included in the analysis.

\subsection{Environmental Sustainability Vs. Economic Growth - A review}

The most common approach to show the relationship between per capita income ( $\mathrm{PCl}$ ) (as a measure of economic development) and environmental quality (or degradation) is to look for the possibility to have an inverted U-shaped curve in the $\mathrm{PCl}$ vs. environmental quality plane. The curve is known as EKC, which shows that with the rise in $\mathrm{PCl}$, environmental quality degrades; the environmental degradation continues upto a certain level of $\mathrm{PCl}$ and then it starts to improve as countries become rich so as to spend resources on pollution mitigation and using cleaner production technologies. Recently several researchers have come out with empirical results, which show that a limited number of local pollutants (e.g., Sulphur dioxide $\left(\mathrm{SO}_{2}\right)$, Suspended Particulate Matter (SPM), Carbon monoxide (CO) emissions etc.) support EKC hypothesis, other pollutants follow either monotonicity or N-shaped curve. ${ }^{6}$ Studies by Baldwin (1995), Grossman and

\footnotetext{
${ }^{6}$ For a comprehensive review of literature on EKC hypothesis see Dinda (2004) and Stern (1998).
} 
Krueger (1995), Selden and Song (1994), Panayotou (1993), Shafiq and Bandyopadhyay (1992) and Pezzey (1989) based on ambient concentration of pollutants support EKC hypothesis. Similarly, studies conducted by Bruvoll and Medin (2003); de Bruyn et al. (1998) and Carson et al. (1997), considering the actual emission of pollutants instead of their ambient concentration also support the EKC hypothesis.

However most of the studies on EKC have considered only a few pollutants, and have come out with individual pollutant wise EKC. Choosing few pollutants and verifying the EKC might not be true reflection of economic activity and its polluting nature. This is because of two reasons - (a) the economic activity, which generates that pollutant, may not have significant impact on the economy to substantially influence the $\mathrm{PCl}$ or vice versa; and (b) ambient concentration of pollutant is not only function of its actual emission but also depends on several other factors which influence its dispersion and assimilation. ${ }^{7}$ Therefore instead of single pollutant, if we take a composite indicator of pollutants, it would show the actual environmental quality. The only study that has looked into the environment quality as a whole is by Jha and Bhanu Murthy (2001). The authors construct an environmental degradation index (EDI) for 174 countries and compare that with human development index ( $\mathrm{HDI}$ ) instead of $\mathrm{PCl}$. The study finds inverse link between EDI and $\mathrm{HDI}$ and do not find supporting evidence for inverted U-shaped EKC. The study shows that an inverted N-shaped global EKC does indeed exist.

The present study attempts to establish the EKC relationship between per capita NSDP and environmental quality as a whole instead of using only selected pollutants.

\footnotetext{
${ }^{7}$ Refer Kathuria $(2004,2002)$ indicating the relevance of other factors in influencing ambient air quality.
} 


\section{Methodology, Data Sources and Descriptions of the Variables}

\subsection{Methodology}

The depletion and degradation of natural resources and environmental pollution is mainly an environmental management aspect, whereas the endowments of natural resources (forests, land and water) are mostly driven by the geographical location of the State and the prevailing climatic and ecological situations. As a result, human activities have limited impact on latter. However, the two effects (endowment effect and efficiency in natural resource management effect) can be segregated by the change in the natural resource position with reference to a base year. As for example, comparing the forest resources (simply by taking the percentage of geographical area under forests land) between Madhya Pradesh and Rajasthan may show Madhya Pradesh standing apart from Rajasthan, but it will be erroneous to conclude that forest conservation practices of Madhya Pradesh are better as compared to Rajasthan. This is because Rajasthan is endowed with very little forest resources. However, if we take the change in the forest area (as a percentage of geographical area) during any two periods and rank them, one can infer about their forest conservation practices. This study considers the environmental management efficiency effect, besides taking into consideration the size effect of the States.

\subsection{Steps I nvolved}

The analysis is carried out in three steps. In Step 1, after normalisation of the indicators, Principal Component Analysis (PCA) method of factor analysis is used to construct a composite indicator for an environmental group. ${ }^{8}$ For each environmental group, the first factor score is used to rank the States. The underlying assumption is that with all the

${ }^{8}$ Each environmental group constitutes a large number of environmental indicators (refer Appendix 2) from which a composite indicator is derived. 
indicators of a group taken together, the set determines situation of the State with respect to that variable (environmental quality). In other words, all the indicators of a variable when combined for a certain State should reflect the environmental status of the State with respect to that particular criterion. For example, the ambient condition of air pollution in a State is not manifested by only SPM concentration, but by the concentration of all the pollutants $\left(\mathrm{SO}_{2}\right.$, Oxides of nitrogen (NOX), SPM) in both - residential and industrial areas.

In Step 2, based on Borda rule, ${ }^{9}$ a broad environmental quality score $\left(E Q S_{i}\right)$ is constructed by adding the ranks obtained by each State with respect to the individual environmental groups. If $E_{i j}$ is the rank of the $i^{\text {th }}$ State with respect to $j^{\text {th }}$ environmental variable (group), then EQS $S_{i}$ of the $i^{\text {th }}$ State for 8 environmental groups is:

$$
\mathrm{EQS}_{i}=\sum_{j=1}^{8} E_{i j}
$$

In Step 3, the States are ranked according to their EQS $S_{\text {, }}$ where environmental quality rank (EQRANK) of the $i^{\text {th }}$ State is the rank of the State with respect to $E Q S_{i}$ over $i=1$ to 14 .

In the second part of the paper, EKC hypothesis is tested by running multivariate regression equation using EQS as dependent variable and log of per capita income (LNPCl) as independent variable. Since the relation between the two is inverted U-shape, the non-linearity is accounted for by taking a square of the income term $\left(\mathrm{LNPCl}^{2}\right)$. The literature suggests that the pollution (or environmental quality) is affected not only by the income but also by a number of other variables like share of agriculture in GDP or what proportion of employment is dependent on primary sector or population density or awareness etc. (see for example Aldy, 2004; Andreoni and

\footnotetext{
${ }^{9}$ The Borda Rule or Borda rank is the rank order scoring rule for ordinal aggregation. The rule can also be viewed as voting rule, where under each environmental criterion (voter), the States are ranked (voted) from high to low EQ. The rule invariably yields a complete ranking of alternatives (see Dasgupta, 2001).
} 
Levinson, 2001 and Grossman and Krueger, 1995 among others $\left.{ }^{10}\right)$. Thus, following equation is estimated to establish the EKC hypothesis:

$$
E Q S_{i t}=\alpha+\beta_{0} L N P C I_{i t}+\beta_{1} L N P C I_{i t}{ }^{2}+\gamma X_{i t}+\varepsilon_{i t}
$$

where, $\mathrm{i}=1$ to 14 and $\mathrm{t}$ is the two time periods for which data is pooled and $\varepsilon_{\mathrm{i}}$ is the error term and $\varepsilon_{i} \sim N(0,1)$, iid; $X_{i}$ captures all other explanatory variables (e.g., share of agriculture in GSDP (AGR), workers in agricultural sector (AGRWRK), rural literacy rate (LITRU), extent of urbanization (URB), share of manufacturing (MFG)). The saddle point of the EKC is obtained from first order condition of equation 1.

$$
P C I^{*}=\exp (\stackrel{\Lambda}{L N P C I})=\exp \left(\frac{-\hat{\beta}_{0}}{2 \hat{\beta}_{1}}\right)
$$

\subsection{Data and Variables}

As indicated, the study considers 14 major Indian States - viz., Andhra Pradesh (AP), Bihar (BH), Gujarat (GUJ), Haryana (HR), Karnataka (KAR), Kerala (KER), Madhya Pradesh (MP), Maharashtra (MH), Orissa (OR), Punjab (PB), Rajasthan (RAJ), Tamilnadu (TN), Uttar Pradesh (UP) and West Bengal (WB) - for which environmental information are available for the two broad time periods - (a) early 1990s (1990-1996); and (b) late 1990s (19972001). Since the data for various environmental indicators are available for different time points, which are not necessarily falling within the time period selected for our analysis, we have taken only those indicators which have at

\footnotetext{
${ }^{10}$ It is to be noted that these relationships are easy to conceptualise, if one is trying to find relationship between a particular environment indicator (say $\mathrm{CO}_{2}$ ) and income. However, for a composite index, the relationship is difficult to predict. For example, increased urbanisation may lead to increased urban air pollution, but may also lead to fall in non-point source pollution, if the city is adequately covered with water and sanitation. In those circumstances, the relationship is more of exploratory.
} 
least two observations, and one of these observations falling within the boundary of our two time periods.

This analysis is mostly based on the State level secondary information available in various published government reports and databases. Appendix 1 gives the list of various sources used for the analysis. The indicators have been normalised using appropriate measures of size/scale of the States - geographical area, population and Gross State Domestic Product (GSDP) at current prices. After an extensive literature review and based on the data availability at the State level, for both the periods 63 environmental status indicators are grouped under 8 broad environmental variables as given in Table 2. Appendix 2 gives the descriptions of the groups and different indicators used to form each group.

Table 2: Descriptions of the Environmental Groups

\begin{tabular}{|l|l|c|}
\hline \multicolumn{1}{|c|}{ Groups } & \multicolumn{1}{c|}{ Group Descriptions } & Number of Indicators \\
\hline AIRPOL & Air Pollution & 6 \\
\hline INDOOR & Indoor Air Pollution Potential & 6 \\
\hline GHGS & Green House Gases (GHGs) Emissions & 4 \\
\hline ENERGY & Pollution from Energy Generation and Consumption & 12 \\
\hline FOREST & Depletion and Degradation of Forest Resources & 11 \\
\hline WATER & Depletion and Degradation of Water Resources & 10 \\
\hline NPSP & Nonpoint Source Water Pollution Potential & 7 \\
\hline LAND & Pressure and Degradation of Land Resources & 7 \\
\hline & Total & $\mathbf{6 3}$ \\
\hline
\end{tabular}




\subsection{Construction of Variables for EKC}

As the second part of the paper involves verifying EKC, various control variables have been used. The share of agriculture in GSDP (AGR) has been computed as the average for the period 1993-94 to 1995-96 for period 1 and average for 1997-98 to $1999-2000$ for period 2. The average is taken to smoothen out uneven fluctuations. AGRWRK is the agricultural workers (including cultivators and agricultural labourers) as a percentage of total workers. LITRU is the percentage of rural literate population (defined as 7 years and above). Apart from this, Urbanisation (URB), i.e., extent of people living in urban areas and share of Manufacturing in GSDP (MFG) are also included.

\subsection{Estimation I ssues}

For factor analysis, Varimax (with Kaiser normalisation) method of factor rotation ${ }^{11}$ is applied using SPSS Statistical Software (Version 9.05). The Kaiser-Meyer-Olkin (KMO) measure ${ }^{12}$ of sampling adequacy criteria has been used to select a set of indicators for the factor analysis. Test statistics indicate that in most cases it is greater than 0.60 and Bartlett's test of sphericity ${ }^{13}$ is also significant at 0.01 level in most cases.

To verify the EKC hypothesis, multivariate OLS regressions are carried out with EQS as dependent variable and log PCNSDP, log PCNSDP ${ }^{2}$ and other controlling variables. The estimation is carried out by pooling the data for both the periods with a dummy variable for period 2 .

\footnotetext{
${ }^{11}$ Factor analysis attempts to identify underlying variables/ factors, that explain the pattern of correlations within a set of observed variables. The need for PCA is because some of the variables in a group may be correlated; dropping them will result in loosing vital information.

${ }^{12}$ KMO measure of sampling adequacy tests whether the partial correlations among variables are small or not.

${ }^{13}$ Bartlett's test of sphericity tests whether the correlation matrix is an identity matrix, which would indicate that the factor model is inappropriate. The tests are significant at 0.01 level, thus indicating model appropriateness.
} 


\section{Results - Constructing Environmental Quality Scores}

\subsection{Environmental Ranking of States during early 1990s}

Table 3 gives the EQ score and ranking of 14 major Indian states for period 1. It shows that during the early 1990s, Orissa, AP, Kerala and WB are the four better performing States with respect to environmental quality. On the other hand, Haryana, Punjab, Gujarat and Maharashtra are the four worst performing States. AP and Orissa have the highest EQ ranking, as both the States have done well in almost all the aspects of EQ. Except in indoor air pollution control, Haryana has done badly in almost all other criteria. From the table it is evident that different States have different strengths and weaknesses in managing various aspects of environmental quality. For instance, in early 1990s Kerala has managed air and indoor air pollution well, whereas WB has done well in water resource management and so on.

Table 3: Ranks obtained by States for different EQ Criteria - Early 1990s

\begin{tabular}{|c|c|c|c|c|c|c|c|c|c|c|}
\hline $\begin{array}{l}\text { Criteria } \\
\text { State }\end{array}$ & $\begin{array}{c}\text { AIRPOL } \\
\text { (1) }\end{array}$ & $\begin{array}{c}\text { INDOOR } \\
\text { (2) }\end{array}$ & $\begin{array}{c}\text { GHGS } \\
\text { (3) }\end{array}$ & $\begin{array}{c}\text { ENERGY } \\
(4)\end{array}$ & $\begin{array}{c}\text { FOREST } \\
(5)\end{array}$ & $\begin{array}{c}\text { WATER } \\
\text { (6) }\end{array}$ & $\begin{array}{c}\text { NPSP } \\
(7)\end{array}$ & $\begin{array}{c}\text { LAND } \\
(8)\end{array}$ & $\begin{array}{c}\text { EQ } \\
\text { Score } \\
(9)\end{array}$ & $\begin{array}{c}\text { EQRANK } \\
(10)\end{array}$ \\
\hline Andhra Pradesh & 4 & 3 & 4 & 3 & 1 & 4 & 12 & 3 & 34 & 1 \\
\hline Bihar & 10 & 13 & 1 & 1 & 11 & 5 & 6 & 6 & 53 & 6 \\
\hline Gujarat & 12 & 11 & 8 & 12 & 8 & 8 & 9 & 12 & 80 & 12 \\
\hline Haryana & 6 & 9 & 12 & 13 & 7 & 12 & 13 & 14 & 86 & 14 \\
\hline Karnataka & 7 & 5 & 13 & 9 & 10 & 10 & 7 & 2 & 63 & 9 \\
\hline Kerala & 1 & 1 & 14 & 7 & 6 & 6 & 4 & 5 & 44 & 3 \\
\hline Madhya Pradesh & 14 & 6 & 2 & 6 & 14 & 3 & 2 & 10 & 57 & 7 \\
\hline Maharashtra & 8 & 12 & 9 & 11 & 13 & 9 & 3 & 11 & 76 & 11 \\
\hline Orissa & 2 & 7 & 5 & 4 & 12 & 2 & 1 & 1 & 34 & 1 \\
\hline Punjab & 9 & 10 & 11 & 14 & 2 & 14 & 14 & 8 & 82 & 13 \\
\hline Rajasthan & 11 & 4 & 10 & 10 & 9 & 11 & 5 & 13 & 73 & 10 \\
\hline Tamilnadu & 3 & 2 & 6 & 8 & 5 & 13 & 10 & 4 & 51 & 5 \\
\hline Uttar Pradesh & 13 & 8 & 3 & 5 & 3 & 7 & 11 & 7 & 57 & 7 \\
\hline West Bengal & 5 & 14 & 7 & 2 & 4 & 1 & 8 & 9 & 50 & 4 \\
\hline
\end{tabular}

Note: EQ Score is obtained using Borda Rule 


\subsection{Environmental Ranking of States during late 1990s}

Table 4 shows that during the late 1990s, MP, Orissa, Bihar and UP are the four better performing States. Row 7 indicates that MP not only has secured the highest rank but also has done well in almost all the environmental criteria. Haryana, Punjab, WB and TN are however the four worst performing States. Haryana has done poorly in almost all the environmental criteria.

Table 4: Ranks obtained by States for different EQ Criteria - Late 1990s

\begin{tabular}{|l|c|c|c|c|c|c|c|c|c|c|}
\hline \multicolumn{1}{|c|}{ Criteria } & AIRPOL & INDOOR & GHGS & ENERGY & FOREST & WATER & NPSP & LAND & EQ Score & EQRANK \\
\hline States & $\mathbf{( 1 )}$ & $\mathbf{( 2 )}$ & $\mathbf{( 3 )}$ & $\mathbf{( 4 )}$ & $\mathbf{( 5 )}$ & $\mathbf{( 6 )}$ & $\mathbf{( 7 )}$ & $\mathbf{( 8 )}$ & $\mathbf{( 9 )}$ & $\mathbf{( 1 0 )}$ \\
\hline Andhra Pradesh & 2 & 9 & 4 & 3 & 5 & 9 & 12 & 10 & 54 & 6 \\
\hline Bihar & $\mathbf{1 4}$ & $\mathbf{1}$ & 2 & $\mathbf{1}$ & 12 & 3 & 3 & 6 & 42 & 3 \\
\hline Gujarat & 9 & 13 & 10 & 7 & 8 & 4 & 9 & 4 & 64 & 9 \\
\hline Haryana & 11 & 11 & $\mathbf{1 4}$ & $\mathbf{1 4}$ & 13 & 11 & 13 & 13 & $\mathbf{1 0 0}$ & $\mathbf{1 4}$ \\
\hline Karnataka & 12 & 7 & 11 & 8 & 4 & 10 & 7 & 9 & 68 & 11 \\
\hline Kerala & 6 & 10 & 12 & 11 & 3 & 5 & 6 & 5 & 58 & 7 \\
\hline Madhya Pradesh & 7 & 4 & 3 & 5 & $\mathbf{1}$ & $\mathbf{1}$ & 2 & $\mathbf{1}$ & $\mathbf{2 4}$ & $\mathbf{1}$ \\
\hline Maharashtra & 3 & 12 & 7 & 2 & 7 & 6 & 5 & 8 & 50 & 5 \\
\hline Orissa & 8 & 6 & 5 & 4 & 10 & 2 & $\mathbf{1}$ & 2 & 38 & 2 \\
\hline Punjab & 4 & $\mathbf{1 4}$ & 13 & 13 & $\mathbf{1 4}$ & 13 & $\mathbf{1 4}$ & $\mathbf{1 4}$ & 99 & 13 \\
\hline Rajasthan & $\mathbf{1}$ & 3 & 9 & 10 & 11 & 12 & 4 & 12 & 62 & 8 \\
\hline Tamilnadu & 5 & 8 & 8 & 12 & 9 & $\mathbf{1 4}$ & 10 & 3 & 69 & 12 \\
\hline Uttar Pradesh & 10 & 2 & $\mathbf{1}$ & 6 & 2 & 7 & 11 & 7 & 46 & 4 \\
\hline West Bengal & 13 & 5 & 6 & 9 & 6 & 8 & 8 & 11 & 66 & 10 \\
\hline
\end{tabular}

\subsection{Environmental Quality Scores - Comparison across Periods}

Figure 1 plots the EQ scores for both the periods. A place on the North-East corner implies poor EQ; whereas place on the South-West corner indicates better EQ vis-à-vis other States. Similarly, place on the North-West 
corner means EQ has degraded in the State and position on the South-East corner means improvement in EQ over the period.

Figure 1: Environmental Quality Scores over Periods

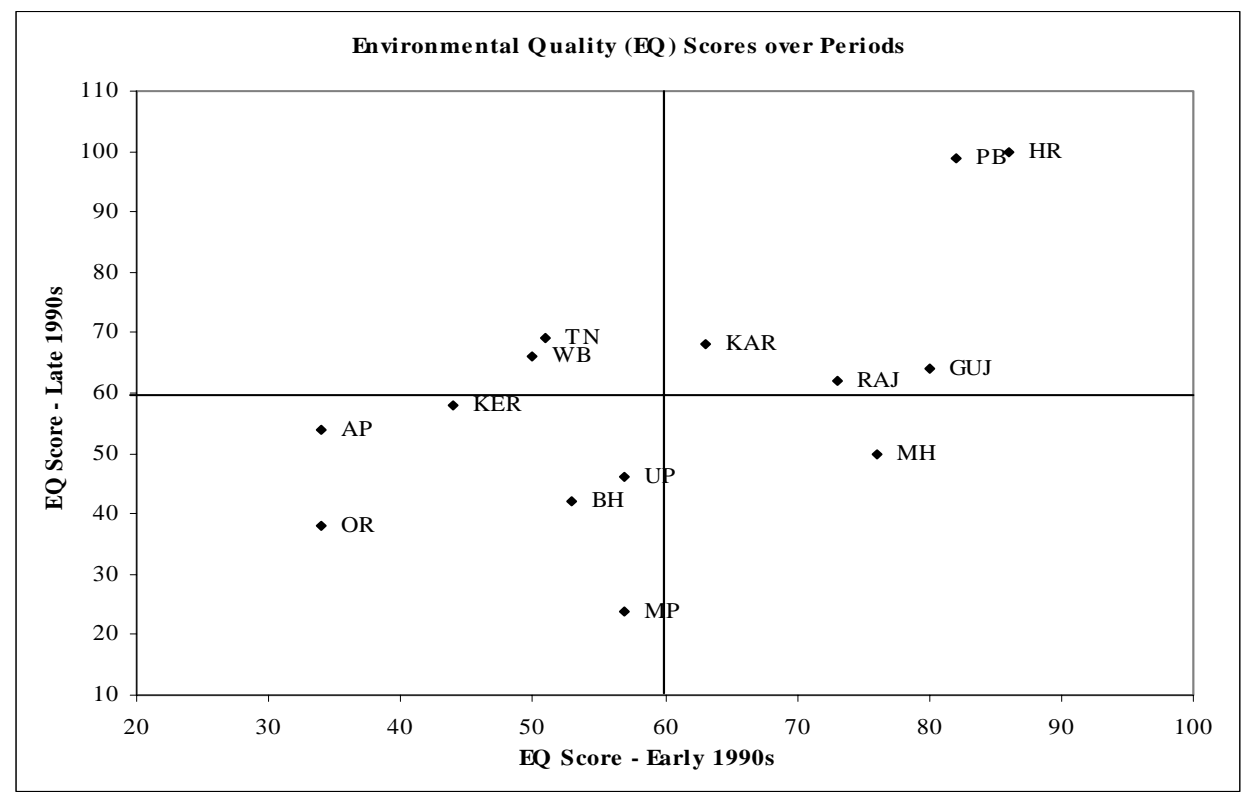

The figure shows that Orissa has done well in both the periods with respect to environmental quality. During late 1990s EQ Scores of AP, Kerala, WB, and TN have gone up substantially, which implies that environmental quality of these States has degraded during the period. For Punjab and Haryana, the environmental quality has degraded further during late 1990s. EQ Scores of MP, BH, UP, Rajasthan, Maharashtra and Gujarat has declined as compared to the earlier scores. The environmental quality improvement for MP is quite substantial, whereas for Karnataka, it has remained unchanged. Based on the plot, it can be concluded that States like Haryana and Punjab need special attention to check their environmental degradation. 


\section{Results - Testing for Environmental Kuznets Curve}

\subsection{Economic Development Vs. Environmental Quality}

The relationship between economic development and EQ is complex. The present study measures the economic development of the States by the Per Capita Net State Domestic Product (PCNSDP) at constant (1993-94) prices. PCNSDP for the early 1990s is the average PCNSDP for the period 1993-94 to 1995-96 and for the late 1990s is for the period 1997-98 to 1999$2000 .{ }^{14}$ Table 5 gives the per capita income of the 14 States for the two periods. From the table, it can be seen that Punjab, Maharashtra, Haryana, Gujarat and TN are high income States, wherever Bihar, Orissa, UP and MP are low income states. ${ }^{15}$

Figures 2 and 3 plot environmental quality scores against the PCNSDP for early nineties and late nineties respectively. Figure 2 shows that among all the States, Orissa and AP have the best environmental quality. Though Orissa falls under the low income States, its environmental quality is the best. Except for Karnataka, all the middle income States have environmental quality better than the high and low income States, except Orissa. Though per capita income is low for Bihar, Orissa, UP and MP, they seem to have managed environment better as compared to agriculturally and industrially developed States like Haryana, Punjab, Gujarat and Maharashtra.

\footnotetext{
${ }^{14}$ The reason for taking average over three year period is because many of the environmental variables are not for the same year. Moreover, taking average smoothens any (unanticipated) fluctuation during the period.

15 The States are categorized into low, middle and high income groups according to the first and third quartile of the PCNSDP. For early 1990s, first and third quartiles are approximately Rs. 7,000 and Rs. 11,000 respectively, whereas for late 1990s they are approximately Rs. 8,000 and Rs. 13,000 respectively.
} 
Table 5: Per Capita Income and Ranks

\begin{tabular}{|l|c|c|c|c|c|c|}
\hline \multirow{2}{*}{ States } & \multicolumn{2}{|c|}{$\begin{array}{c}\text { Average PCNSDP: } \\
\text { Early 1990s (in } \\
\text { Rs./head/year) }\end{array}$} & $\begin{array}{c}\text { Average PCNSDP: } \\
\text { Late 1990s (in } \\
\text { Rs./head/year) }\end{array}$ & $\begin{array}{c}\text { EQ Score: } \\
\text { Early 1990s }\end{array}$ & $\begin{array}{c}\text { EQ Score: } \\
\text { Late 1990s }\end{array}$ \\
\cline { 2 - 8 } & \multicolumn{2}{|c|}{$(\mathbf{1})$} & \multicolumn{2}{|c|}{$\mathbf{( 2 )}$} & $\mathbf{( 3 )}$ & $\mathbf{( 4 )}$ \\
\hline Andhra Pradesh & 7,757 & $\mathbf{( 8 )}$ & 8,944 & $\mathbf{( 8 )}$ & $\mathbf{3 4}$ & 54 \\
\hline Bihar & 3,045 & $\mathbf{( 1 4 )}$ & 3,213 & $\mathbf{( 1 4 )}$ & 53 & 42 \\
\hline Gujarat & 10,993 & $\mathbf{( 4 )}$ & 13,151 & $\mathbf{( 3 )}$ & 80 & 64 \\
\hline Haryana & 11,426 & $\mathbf{( 3 )}$ & 13,085 & $\mathbf{( 4 )}$ & $\mathbf{8 6}$ & $\mathbf{1 0 0}$ \\
\hline Karnataka & 8,101 & $\mathbf{( 7 )}$ & 10,360 & $(6)$ & 63 & 68 \\
\hline Kerala & 8,401 & $(6)$ & 9,625 & $(7)$ & 44 & 58 \\
\hline Madhya Pradesh & 6,631 & $\mathbf{( 1 1 )}$ & 7,623 & $\mathbf{( 1 1 )}$ & 57 & $\mathbf{2 4}$ \\
\hline Maharashtra & 12,521 & $\mathbf{( 2 )}$ & 14,282 & $\mathbf{( 2 )}$ & 76 & 50 \\
\hline Orissa & 4,921 & $\mathbf{( 1 3 )}$ & 5,234 & $\mathbf{( 1 3 )}$ & $\mathbf{3 4}$ & 38 \\
\hline Punjab & 12,834 & $\mathbf{( 1 )}$ & 14,337 & $\mathbf{( 1 )}$ & 82 & 99 \\
\hline Rajasthan & 6,844 & $\mathbf{( 1 0 )}$ & 8,687 & $\mathbf{( 1 0 )}$ & 73 & 62 \\
\hline Tamilnadu & 9,686 & $\mathbf{( 5 )}$ & 11,808 & $\mathbf{( 5 )}$ & 51 & 69 \\
\hline Uttar Pradesh & 5,156 & $\mathbf{( 1 2 )}$ & 5,542 & $\mathbf{( 1 2 )}$ & 57 & 46 \\
\hline West Bengal & 7,114 & $\mathbf{( 9 )}$ & 8,851 & $\mathbf{( 9 )}$ & 50 & 66 \\
\hline
\end{tabular}

Source: EPWRF (2003)

Note: Figure in the parenthesis shows the PCNSDP rank

Figure 2: Economic Development Vs. Environmental Quality - Early 1990s

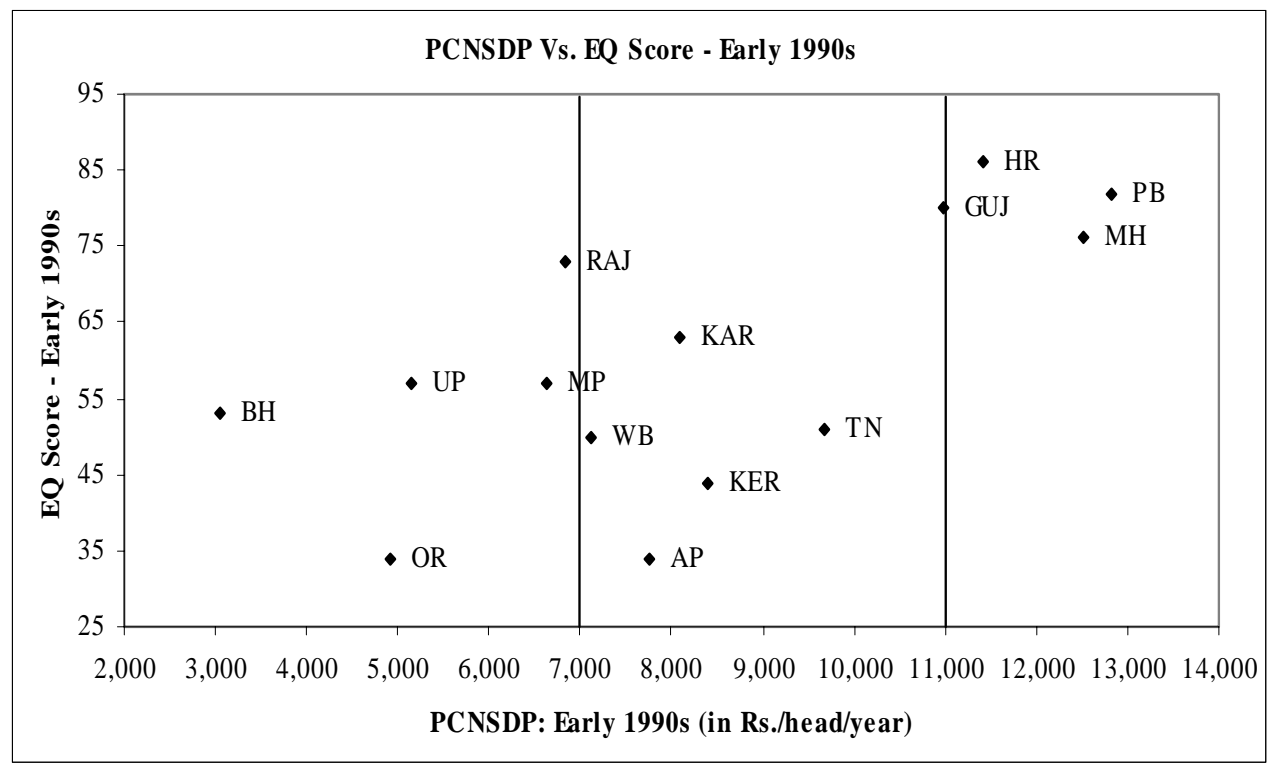


Figure 3 shows that during late 1990s, with some exceptions all the low income States have better environmental quality as compared to the middle and high income States. In comparison to early 1990s, the environmental quality of low income States has improved substantially during late 1990s. The environmental degradation in middle-income States is quite evident during late 1990s, however the environmental quality of Gujarat and MP has improved substantially. With some exceptions, it shows that with the growth in per capita income $(\mathrm{PCl})$, environmental quality tends to fall. States like Punjab, Haryana, Karnataka and TN, though have higher PCl rank low in environmental quality, whereas States like, Bihar, Orissa, MP and UP though have lower $\mathrm{PCl}$, their environmental quality is better. Figure thus points out an inverse relationship between income and environmental quality.

Figure 3: Economic Development Vs. Environmental Quality - Late 1990s

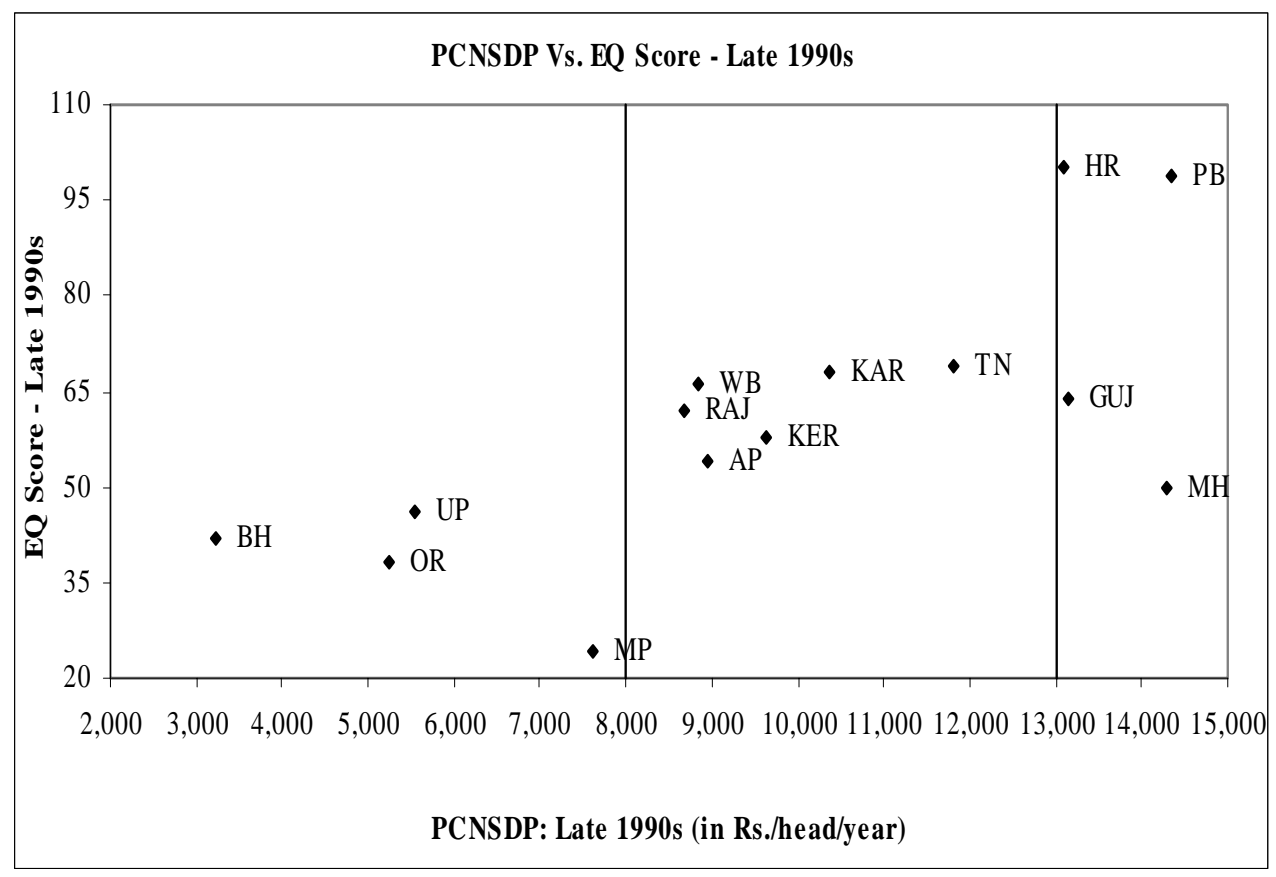




\subsection{Verification for the EKC hypothesis for I ndian States}

To verify the EKC hypothesis, multivariate OLS regressions are carried out. ${ }^{16}$ Before moving to estimation of EKC, it needs to be stated that recent studies verifying EKC have used higher order specifications instead of quadratic (see for example, Aldy, 2004). These researchers have argued that one of the reasons for getting a peak outside the estimated function is because of use of quadratic specification, which is restrictive. The present study also suffers from the same limitation, as it could not use higher order specifications due to data inadequacy. As a consequence, the restricted regression function may give us only the first saddle point and not the subsequent saddle point.

Table 6 reports the results and the saddle point for different variants of model. From the table, it can be seen that there is non-linearity with respect to per capita income (rows 2 and 3). With respect to controlling variables, it can be easily seen that with the growing share of agriculture in GSDP (AGR), the EQ declines. This is because with the rise in agricultural intensity, pressure on land, water and forest resources start mounting up; as a result EQ degrades. Similarly, increased share of workers in agriculture (AGRWRK) also puts pressure on agricultural land and results in environmental degradation. ${ }^{17}$ With respect to LITRU, as the rural literacy rate increases EQS declines, which implies that spread of schooling and hence literate population may be putting pressure on administration to manage pollution and natural resources better.

\footnotetext{
16 Urbanisation, Share of Manufacturing in GSDP and Population Density though are important determinants of EQ, could not be used as they are found to be highly correlated with other explanatory variables.

${ }^{17}$ Given high correlation between AGR and AGRWRK $(\approx 0.5)$, they have been used interchangeably in the model.
} 
Table 6: Verification of EKC

(Dependent Variable: Environmental Quality Score, EQS) (N=28)

\begin{tabular}{|c|c|c|c|c|c|c|c|}
\hline & Explanatory Variable & Coefficient & Coefficient & Coefficient & Coefficient & Coefficient & Coefficient \\
\hline 1 & Constant & $\begin{array}{c}2148.5^{*} \\
(1102.91)\end{array}$ & $\begin{array}{c}2245.8^{*} \\
(1163.34)\end{array}$ & $\begin{array}{l}1779.3^{*} \\
\text { (965.44) }\end{array}$ & $\begin{array}{c}2115.5^{*} \\
(1058.27)\end{array}$ & $\begin{array}{l}1737.9^{*} \\
(976.04)\end{array}$ & $\begin{array}{c}2335.7^{*} \\
(1096.91)\end{array}$ \\
\hline 2 & LNPCI & $\begin{array}{l}-501.0 * \\
(254.17)\end{array}$ & $\begin{array}{l}-529.2^{*} \\
(270.33)\end{array}$ & $\begin{array}{l}-435.5^{*} \\
(218.08)\end{array}$ & $\begin{array}{l}-495.7^{*} \\
(243.6)\end{array}$ & $\begin{array}{l}-427.6^{*} \\
(220.04)\end{array}$ & $\begin{array}{l}-551.4^{*} \\
(253.41)\end{array}$ \\
\hline 3 & $\mathrm{LNPCI}^{2}$ & $\begin{array}{l}29.8^{*} \\
(14.6) \\
\end{array}$ & $\begin{array}{c}31.8 * \\
(15.45)\end{array}$ & $\begin{array}{c}26.9 * \\
(12.34)\end{array}$ & $\begin{array}{l}29.9 * \\
(13.93)\end{array}$ & $\begin{array}{c}26.3^{*} \\
(12.46)\end{array}$ & $\begin{array}{c}32.9 * \\
(14.58)\end{array}$ \\
\hline 4 & AGR & & & $\begin{array}{c}0.8^{*} \\
(0.39) \\
\end{array}$ & & $\begin{array}{c}0.9^{*} \\
(0.36) \\
\end{array}$ & \\
\hline 5 & AGRWRK & & $\begin{array}{c}0.27 \\
(0.39)\end{array}$ & & & & $\begin{array}{c}0.4^{*} \\
(0.18)\end{array}$ \\
\hline 6 & LITRU & & $\begin{array}{l}-0.22 \\
(0.36)\end{array}$ & $\begin{array}{l}-0.26 \\
(0.2) \\
\end{array}$ & $\begin{array}{l}-0.39 * \\
(0.19)\end{array}$ & & \\
\hline 7 & Adjusted $\mathrm{R}^{2}$ & 0.4 & 0.5 & 0.5 & 0.5 & 0.5 & 0.5 \\
\hline 8 & F-statistic & 11.1 & 7.0 & 8.9 & 9.2 & 11.0 & 9.3 \\
\hline 9 & $\begin{array}{l}\text { Durbin-Watson } \\
\text { statistic }\end{array}$ & 1.6 & 1.6 & 1.6 & 1.7 & 1.6 & 1.6 \\
\hline 10 & 1st Saddle Point (Rs.) & 4,462 & 4,135 & 3,234 & 3,989 & 3,347 & 4,343 \\
\hline
\end{tabular}

Notes: Figure in the parenthesis shows White heteroskedasticity consistent standard error.

* - Coefficient is significant at $10 \%$ level.

Row 10 giving the saddle point indicates that the point varies from Rs. 3,234 to Rs. 4,462 . This is the first saddle point showing a particular PCNSDP above which environmental quality starts to decline. However, except Bihar all other States already have PCNSDP higher than the saddle point indicating that the States are on decreasing environmental quality. This also suggests that EKC follows a slanting S-shaped curve, where environmental quality may improve after reaching a particular per capita income.

In Figure 4, both the actual and estimated EQS are plotted against PCNSDP. ${ }^{18}$ The figure shows that after a certain point with the increase in PCNSDP, EQS rises. The estimated second order polynomial trend shows

${ }^{18}$ With the following specification $E Q S_{i t}=f\left(P C N S D P_{i t}, P C N S D P_{i t}{ }^{2}\right)$ 
that, except Bihar all the other States have PCNSDP above the saddle point. However, Orissa, AP and MP having low PCNSDP have comparatively better environmental quality. Both Haryana and Punjab have high PCNSDP, however their level of environmental degradation is also high. As compared to Haryana and Punjab, Maharashtra and Gujarat have lower EQSs, but maintain high PCNSDP. Both Rajasthan and Kerala are exceptions, as Kerala maintains comparatively better environmental quality with a high level of PCNSDP as compared to Rajasthan and vice versa.

Figure 4: PCNSDP vs. Actual \& Estimated EQS

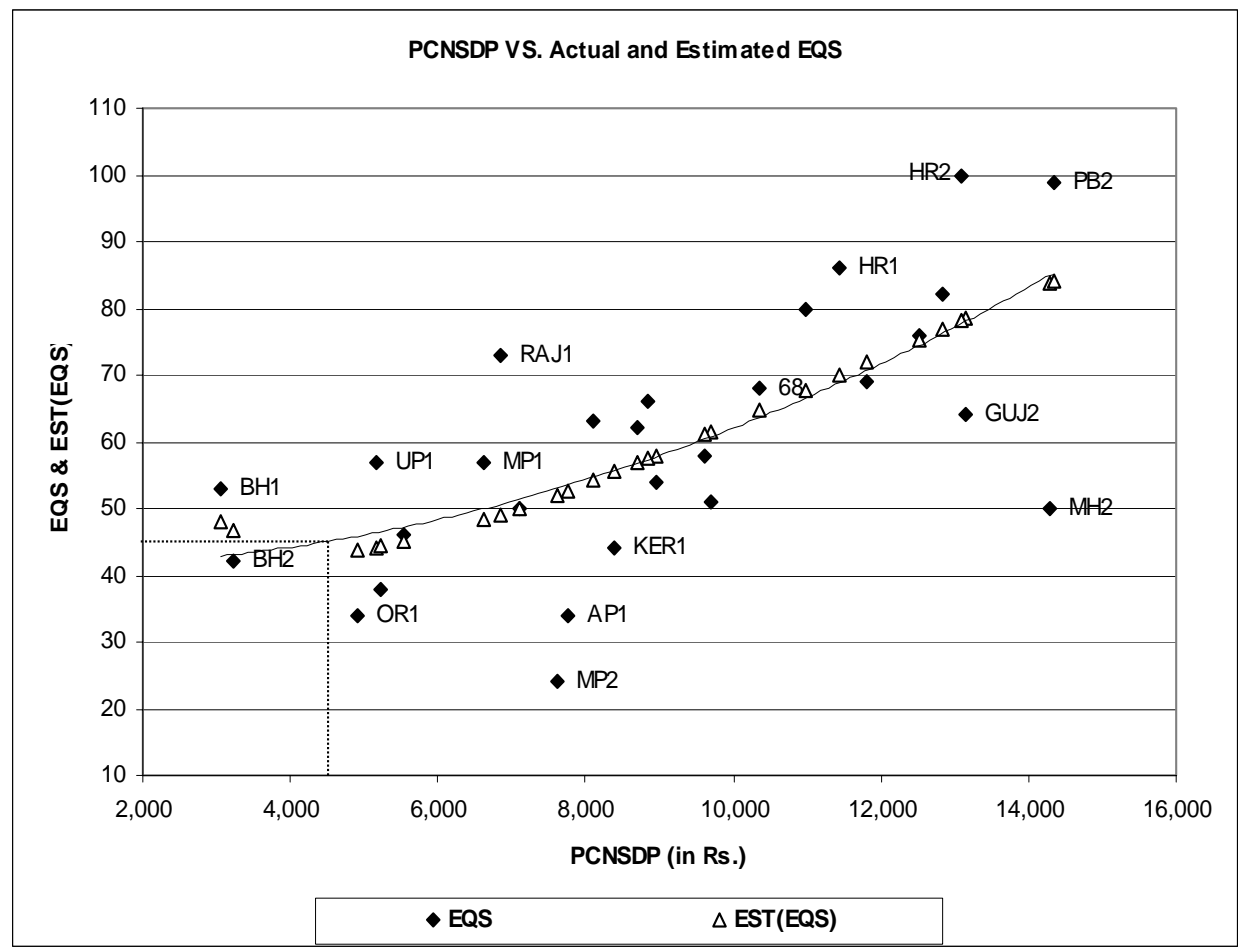

\subsection{Economic Growth Vs. Environmental Degradation}

The last part of the paper looks into what effect economic growth has on change in environmental quality? To investigate, growth in GSDP is 
plotted against the change in EQ. Table 7 gives the annual GSDP growth rates of different States vis-à-vis the change in EQ score over the period.

Table 7: Economic Growth in 1990s vis-à-vis EQ

\begin{tabular}{|l|c|c|r|c|c|}
\hline States & $\begin{array}{c}\text { Average GSDP At } \\
\text { Constant (1993-94) } \\
\text { Prices: Early 1990s } \\
\text { (in Rs. million) } \\
\mathbf{( 1 )}\end{array}$ & $\begin{array}{c}\text { Average GSDP At } \\
\text { Constant (1993-94) } \\
\text { Prices: Late 1990s (in } \\
\text { Rs. million) } \\
\mathbf{( 2 )}\end{array}$ & $\begin{array}{c}\text { Annual } \\
\text { Exponential } \\
\text { GSDP Growth } \\
\text { Rate * } \\
\mathbf{( 3 )}\end{array}$ & $\begin{array}{c}\text { Difference in EQ } \\
\text { Scores (late } \\
\text { 1990s to early } \\
\text { 1990s)\$ } \\
\mathbf{( 4 )}\end{array}$ \\
\hline Andhra Pradesh & 612,364 & 745,116 & 6.5 & $(9)$ & $\mathbf{2 0}$ \\
\hline Bihar & 232,983 & 276,883 & 5.8 & $(12)$ & -11 \\
\hline Gujarat & 561,660 & 738,047 & 9.1 & $(4)$ & -16 \\
\hline Haryana & 233,666 & 291,792 & 7.4 & $(7)$ & 14 \\
\hline Karnataka & 435,444 & 596,862 & 10.5 & $(2)$ & 5 \\
\hline Kerala & 282,050 & 341,209 & 6.3 & $(11)$ & 14 \\
\hline Madhya Pradesh & 395,014 & 491,458 & 7.3 & $(8)$ & $-\mathbf{3 3}$ \\
\hline Maharashtra & $1,196,999$ & $1,510,121$ & 7.7 & $(6)$ & -26 \\
\hline Orissa & 191,146 & 219,641 & $\mathbf{4 . 6}$ & $\mathbf{( 1 4 )}$ & 4 \\
\hline Punjab & 312,735 & 379,992 & 6.5 & $(10)$ & 17 \\
\hline Rajasthan & 372,809 & 518,005 & $\mathbf{1 1 . 0}$ & $\mathbf{( 1 )}$ & -11 \\
\hline Tamilnadu & 631,677 & 807,387 & 8.2 & $\mathbf{( 5 )}$ & 18 \\
\hline Uttar Pradesh & 846,004 & $1,003,749$ & 5.7 & $(13)$ & -11 \\
\hline West Bengal & 572,579 & 757,840 & 9.3 & $\mathbf{( 3 )}$ & 16 \\
\hline
\end{tabular}

Source: EPWRF (2003)

Notes: *Figure in the parenthesis shows the Economic Growth Ranks, where growth rate of a state $=(\ln ($ GSDP late $1990 \mathrm{~s})-\ln ($ GSDP early 1990s) $) / 3 * 100$

$\$$ - Difference in Environmental Quality Scores (EQS) has been computed from Table 6 (= Column $4-$ Column 3).

Column 3 of Table 7 shows that Rajasthan, WB, TN, Gujarat and Maharashtra have grown fast in last decade, wherever States like Orissa, Bihar, UP and MP have less than average growth. Figure 5 plots the economic growth against the change in EQS. The South-East corner is the most desirable location, indicating an economic growth without sacrificing the environment, whereas North-West corner manifest a low growth along with a high relative degradation of environment. 
From Figure 5, it can be inferred that Haryana, TN, WB, and Karnataka have higher economic growth during late 1990s at the cost of their environmental degradation, whereas high economic growth of MP, Maharashtra, Gujarat and Rajasthan has not resulted in much environmental degradation. Though States like Orissa, UP, Bihar, Kerala, Punjab and AP have low economic growth, but seem to have managed their EQ relatively well. For a set of States like MP, Maharashtra, Gujarat and Rajasthan, there is a positive relationship between economic growth and environmental degradation.

Figure 5: Economic Growth Vs. Environmental Degradation

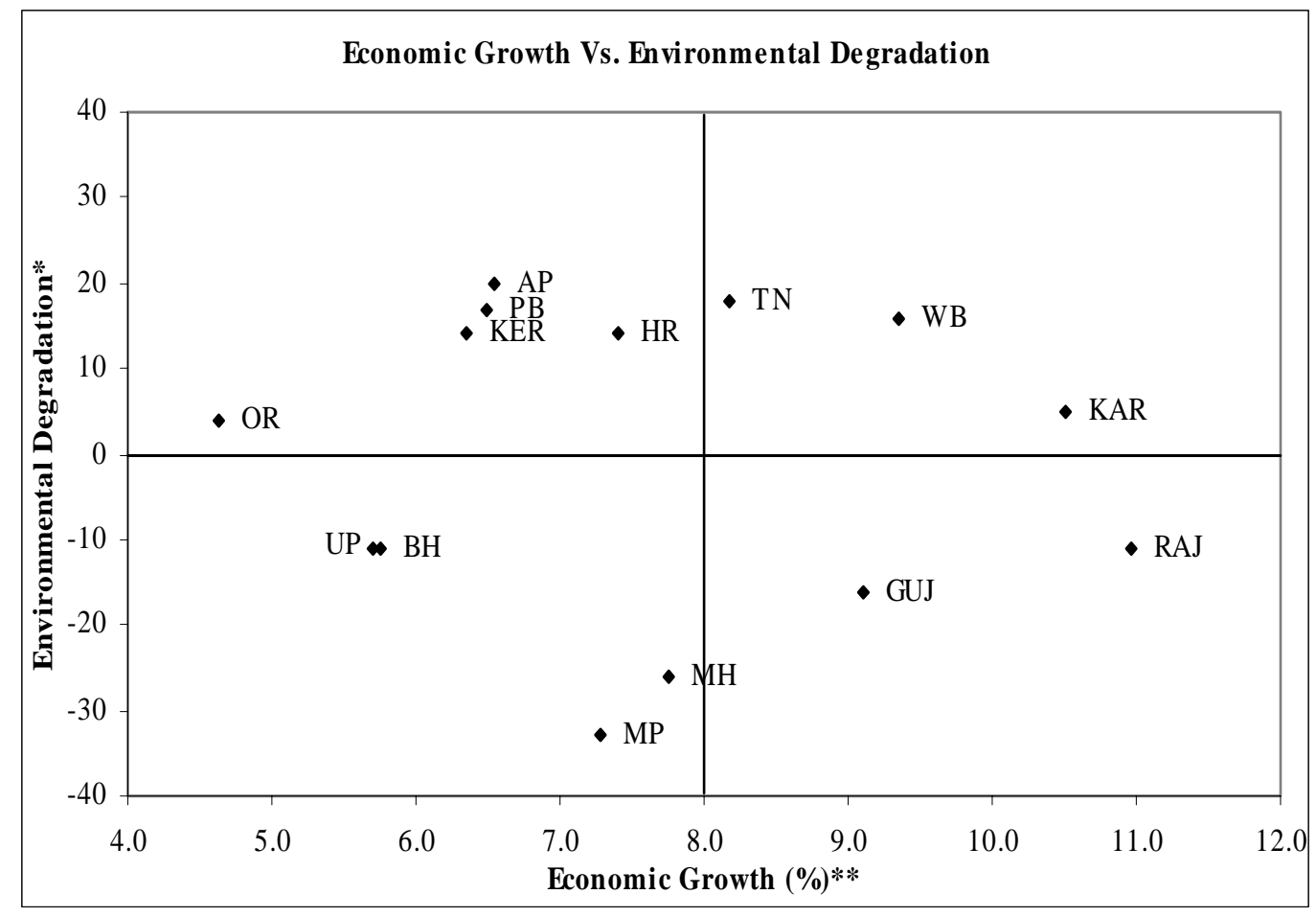

Note: *Environmental degradation is measured by the difference between the EQ Scores from late 1990s to early 1990s; ** Economic growth is measured by the annual exponential growth rate of average GSDP between early 1990s and late 1990s 


\section{Summary and Conclusions}

The economic liberalisation process that began in India in 1991 has resulted in States growing rapidly. A major consequence of this is degradation in environmental quality. Under this backdrop this study measures the environmental performance of 14 major Indian States by ranking them under 8 broad environmental groups. These environmental groups have been derived from a set of 63 environmental indicators by using Principal Component Analysis method of factor analysis. The States are ranked under each of the environmental groups (according to their score in the first factor) and the ranks of the States are added up according to Borda Rule to get the final environmental quality (EQ) score. Final environmental ranks of the States are given on the basis of their EQ score, where States having lower score get higher rank. The States are ranked for two time periods - early 1990s (1990-1996) and late 1990s (1997-2001), and the ranks are compared over period. The paper then investigates the relationship between economic development and environmental quality (i.e., Environmental Kuznets Curve) using a multivariate regression analysis.

Data analysis shows that environmental ranks of the States vary over time, which implies that environment has both spatial and temporal dimensions. Ranking of the States across different environmental criteria (groups) show that different States have different strengths and weaknesses in managing various aspects of environmental quality. Thus, individual states should adopt more focused environmental management practices based on their local (at the most disaggregated level) environmental information (conditions).

Results indicate that the relationship between per capita NSDP and the environmental quality score is non-linear and follows a slanting S-shaped curve, where barring Bihar, all the States are on the declining EQ region. The low income States have better EQ as compared to their rich counterparts. 
Both agriculturally and industrially developed States like Haryana, Punjab, Gujarat and Maharashtra seem to have neglected their environmental issues. The study could not find the point of inflexion, beyond which EQ will start improving. However, taking a cue from developed countries and in consonance with different MDGs (especially Target $9^{19}$ ), there is a wide scope to tunnel the EKC.

The study though could not compute the second inflexion point still has wide policy implications. The quest for faster growth and aiming to integrate with the world economy in nineties has forced many countries in South Asia, South East Asia and Latin America to neglect their environment and conservation of natural resources.

The study has few limitations. The analysis has been restricted to only those 14 Indian States, for which various secondary environmental information are available for both the periods. Thus, the analysis can be extended by including more States. Similarly, the non-availability of data has restricted the analysis for only two broad time periods. Subsequently this analysis can be extended for more periods. Since a number of Indian States are in the process of compiling environmental profile, the analysis can be extended accordingly. Another limitation is use of only a restrictive quadratic function to verify EKC, due to limited degree of freedom. The recent research has attempted to include a higher order polynomial to verify EKC (see for example, Aldy 2004). The main advantage of higher order polynomial is finding both the saddle points, if the relation is slanting $S$. Thus, using more observations can facilitate estimating a higher order polynomial and hence second saddle point. Knowing the second saddle point also facilitate many growing States to plan and tunnel the EKC accordingly.

\footnotetext{
19 Target 9 of MDG specifically stresses on integrating the principles of sustainable development into country policies and programmes and reverse the losses of environmental resources
} 
APPENDIX - 1

Data Sources

\begin{tabular}{|c|c|}
\hline $\begin{array}{l}\text { Environmental } \\
\text { Group }\end{array}$ & Data Sources \\
\hline AIRPOL & $\begin{array}{l}\text { MoEF: National Ambient Air Quality Monitoring Programme } \\
\text { Database }\end{array}$ \\
\hline INDOOR & $\begin{array}{l}\text { TERI: TERI Energy Data Directory and Yearbook (TEDDY) - } \\
\text { Various Years } \\
\text { CSE: State of India's Environment: The Citizens' Fifth Report } \\
\text { (Part II: Statistical Database) } \\
\text { RGI: Census of India } 2001 \text { - Tables on Houses, Amenities } \\
\text { and Assets (Database Software) }\end{array}$ \\
\hline GHGS & $\begin{array}{l}\text { Garg and Shukla (2002) } \\
\text { RGI: Census of India 2001 - CensusInfo India } 2001 \text { (Version } \\
\text { 1.0) - Database Software }\end{array}$ \\
\hline ENERGY & $\begin{array}{l}\text { CMIE: India's Energy Sector - Various Years } \\
\text { TERI: TEDDY - Various Years } \\
\text { RGI: CensusI nfo India } 2001 \\
\text { EPWRF (2003) } \\
\text { CSO: Compendium of Environmental Statistics - } 2000 \text { and } \\
\text { 2002 }\end{array}$ \\
\hline FOREST & $\begin{array}{l}\text { FSI: State of Forest Reports - 1997, } 1999 \text { and } 2001 \\
\text { MoEF: The State of Environment - India: 1999, } 2001 \\
\text { CSE: Citizens' Fifth Report } \\
\text { RGI: CensusI nfo India } 2001 \\
\text { EPWRF (2003) }\end{array}$ \\
\hline WATER & $\begin{array}{l}\text { MoWR: Annual Report - Various Years } \\
\text { CMIE: India's Agriculture Sector - Various Years } \\
\text { MoEF: National Rivers Water Quality Monitoring (NRWQM) } \\
\text { Programme Database } \\
\text { MoA: Annual Report - Various Years } \\
\text { CSE: Citizens' Fifth Report }\end{array}$ \\
\hline NPSP & $\begin{array}{l}\text { CMIE: India's Agriculture Sector - Various Years } \\
\text { MoA: Annual Report - Various Years } \\
\text { DoAHD\&F: Livestock Census Data - 1992, } 1997 \text { and } 2003 \\
\text { RGI: Census of India } 2001 \text { - Tables on Houses, Amenities } \\
\text { and Assets (Database Software) }\end{array}$ \\
\hline LAND & CMIE: India's Agriculture Sector - Various Years \\
\hline
\end{tabular}


Notes:

CMIE: Centre for Monitoring Indian Economy, Mumbai

CSE: Centre for Science and Environment, New Delhi

CSO: Central Statistical Organisation, Ministry of Statistics and Programme Implementation, Government of India (Gol), New Delhi.

DoAHD\&F: Department of Animal Husbandry, Dairying \& Fisheries, MoA, Gol, New Delhi.

EPWRF: Economic and Political Weekly Research Foundation, Mumbai

FSI: Forest Survey of India, Ministry of Environment and Forest, Gol, Dehradun

MoA: Ministry of Agriculture, (Gol), New Delhi

MoEF: Ministry of Environment and Forests, (Gol), New Delhi

MoWR: Ministry of Water Resources, (Gol), New Delhi

$\mathrm{RGI}$ : Office of the Registrar General, Director of Census Operation, Ministry of Home Affairs, (Gol), New Delhi.

TERI: The Energy Resources Institute, New Delhi 


\section{APPENDIX - 2 \\ DESCRIPTIONS OF ENVI RONMENTAL GROUPS (VARI ABLES) \& INDICATORS}

\section{AI R POLLUTI ON (12 indicators)}

- Maximum Concentration of $\mathrm{NO}_{2}, \mathrm{SO}_{2}$ and SPM in Residential and Industrial Area $\left(\mu \mathrm{g} / \mathrm{m}^{3}\right)$ : 1995 and 1999

\section{NDOOR AI R POLLUTION POTENTI AL (12 indicators)}

- Monthly Per-Capita Expenditure (MPCE) on Bio-Fuels as a Percentage of Total Expenditure on Fuels (\%) for Rural and Urban Area: 1993-1994 and 1999-2000

- Percentage of Rural and Urban Households using Bio-fuels (Firewoods and chips, Dung cake) for cooking (\%): 1993-1994 and 1999-2000

- Percentage of Rural and Urban Households Using Unsafe (Wood, Cowdung cake, others) Fuels: 1991

- Percentage of Rural and Urban Households using Unsafe Fuels for cooking (Firewood, Crop residue and Cow dung cake): 2001

\section{GREEN HOUSE GASES EMI SSIONS (8 indicators)}

- $\mathrm{CO}_{2}$ Equivalent GHGs $\left(\mathrm{CO}_{2}, \mathrm{CH}_{4}, \mathrm{~N}_{2} \mathrm{O}\right)$ Emissions (100 Kg. /Person): 1990 and 1995

- $\mathrm{CO}_{2}$ Equivalent GHGs $\left(\mathrm{CO}_{2}, \mathrm{CH}_{4}, \mathrm{~N}_{2} \mathrm{O}\right)$ Emissions (100 Tons/Rs. Crore of NSDP at Factor Cost (Current Prices)): 1990 and 1995

- $\mathrm{CO}_{2}$ Equivalent GHGs $\left(\mathrm{CO}_{2}, \mathrm{CH}_{4}, \mathrm{~N}_{2} \mathrm{O}\right)$ Emissions (1000 Tons/Rs. Per Capita NSDP at Factor Cost (Current Prices)): 1990 and 1995

- Other GHGs (NOx, $\mathrm{SO}_{2}$ ) Emissions (10 Tons/Rs. Per Capita NSDP at Factor Cost (Current Prices)): 1990 and 1995

\section{POLLUTION FROM ENERGY GENERATION AND CONSUMPTION (24 indicators)}

- Change in Electricity Sales to Agriculture as a Percentage of Total Electricity Sales (Percentage points): $1990-91$ to $1995-96$ and 1995-96 to $1998-99$

- Percentage Change in Number of Energised Pumpsets (\%): 1990-91 to 1995-96 and 1995-96 to 1998-99 
- Change in the Share of Thermal Electricity in Gross Electricity Generated (Percentage Points): $1990-91$ to 1995-96 and 1995-96 to 1998-99

- Change in Per Capita Consumption of LPG, MG, K, HSD, LDO (Kg./Person): $1990-91$ to 1995-96 and 1995-96 to 1998-99

- Change in Per Capita Consumption of Electricity (KWh/Person): 1990-91 to $1995-96$ and $1995-96$ to $1998-99$

- Change in Per Capita Generation of Thermal Electricity (KWh/person): 1990-91 to 1995-96 and 1995-96 to 1998-99

- Energy Intensity of Agriculture (100 kWh/Lakh Rs.): 1995-96 and 19992000

- Percentage of Rural and Urban Households Having Access to Electricity: 1991 and 2001

- MPCE on Fuel \& Lighting (Rs./month/head) Rural and Urban Areas: 1993-94 and 1999-2000

- Annual Percentage Increase in Motor Vehicles Number (given geographical area) during 1991-92 to $1995-96$ and $1995-96$ to 20002001

\section{DEPLETION AND DEGRADATION OF FOREST RESOURCES (22 indicators)}

- Change in Dense Forest as a Percentage of Total Forest Area (in percentage points) during 1995 to 1997 and 1999 to 2001

- Change in Open Forest as a Percentage of Total Forest Area (in percentage points) during 1995 to 1997 and 1999 to 2001

- Change in Total Forest Area as a Percentage of Geographical Area (in percentage points) during 1995 to 1997 and 1999 to 2001

- Change in Forest Area Per Thousand Person (in Sq. per 1000 Person) during 1995 to 1997 and 1999 to 2001

- Recorded Forest Area as a Percentage of Geographical Area (\%): 1995 and 2001

- Common Property Forest Area* as a percentage of Total Forest Area: 1995 and 2001

- Common Property Forest Area* as a percentage of Geographical Area (\%): 1995 and 2001

- Common Property Forest Area* Per 1000 Person (Sq. Km. Per 1000 Person): 1995 and 2001

- Percentage of Geographical Area under National Park (\%): 1997 and 1999 
- Percentage of Geographical Area under Wildlife Sanctuaries: 1997 and 1999

- Percentage Change in GSDP at Constant Prices from Forestry \& Logging during 1993-94 to 1996-97 and 1996-97 to 1999-2000

- Note: $*$ - Common Property Forest Area $=$ Protected + Unclassed Forest Area

\section{DEPLETION AND DEGRADATION OF WATER RESOURCES (20 indicators)}

- Percentage Share of Major \& Medium Irrigation Potential Created upto March 1992 and March 1997 to Ultimate Irrigation Potential (\%)

- Percentage Share of Major \& Medium Irrigation Potential Utilised upto March 1992 and March 1997 to Corresponding Potential Created (\%)

- Percentage Share of Minor Irrigation Potential Created upto March 1992 and March 1997 to Ultimate I rrigation Potential (\%)

- Percentage Share of Minor Irrigation Potential Utilised upto March 1992 and March 1997 to Corresponding Potential Created (\%)

- Change in Percentage of Net Irrigated Area irrigated by Surface Water Sources (Canals, Tanks) during 1992-93 to $1995-96$ and $1995-96$ to 2000-2001 (Percentage points)

- Level of groundwater development (exploitation) (\%), 1996 and 1998-99

- Change in Gross I rrigated Area (as a percentage of Gross-Cropped Area) (in percentage points): $1991-92$ to $1995-96$ and 1995-96 to 1998-99

- Pumsets Density (Number Per 1000 ha of Net Irrigated Area), 1994-95 and 1998-99

- Performance in Water Quality Monitoring (No of Monitoring Points for which data is available/Total No of Monitoring Point*100): 1997 and 2001

- Average Water Pollution ( $6=$ very good, $1=$ very bad): 1997 and 2001

\section{NON-POINT SOURCE WATER POLLUTION POTENTIAL (14 indicators)}

- Fertilisers Consumption Per Hectare: (Kg./Hectares): 1995-96 and 19992000

- Pesticides Consumption Per Hectare: (Kg./Hectares): 1995-96 and 19992000

- Change in Number of Livestock Per 1000 Hectares of Reporting Area (Number Per 1000 Hectare) during 1992 to 1997 and 1997 to 2003 
- Change in Number of Persons Per 1000 ha of Reporting Area (Number/1000 ha) during 1991-92 to 1995-96 and 1995-96 to 1998-99

- Number of Persons Per 1000 ha of Reporting Area (Number/1000 ha): 1995-96 and 1998-99

- Change in Gross I rrigated Area (as a percentage of Gross-Cropped Area) (in percentage points): $1991-92$ to $1995-96$ and 1995-96 to 1998-99

- Gross Irrigated Area (Percentage of Gross-Cropped Area): 1995-96 and 1998-99

\section{PRESSURE AND DEGRADATION OF LAND RESOURCES (14 indicators)}

- Change in Land Not Available for Cultivation (as a percentage of reporting area) (in percentage points): 1991-92 to $1995-96$ and 1995-96 to $1998-99$

- Change in Fallow Land (as a percentage of reporting area) (in percentage points): $1991-92$ to $1995-96$ and 1995-96 to 1998-99

- Change in Net Sown Area (as a percentage of reporting area) (in percentage points): $1991-92$ to 1995-96 and 1995-96 to 1998-99

- Change in Area Under Foodgrains (as a percentage of Gross Cropped Area) (in percentage points): $1991-92$ to $1995-96$ and 1995-96 to 199899

- Change in Gross I rrigated Area (as a percentage of Gross-Cropped Area) (in percentage points): $1991-92$ to $1995-96$ and 1995-96 to 1998-99

- Change in Gross Cropped Area (as a percentage of Reporting Area) (in percentage points): $1991-92$ to $1995-96$ and $1995-96$ to $1998-99$

- Change in Area Cultivated More than Once (as a percentage of Gross Cropped Area) (in percentage points): 1991-92 to 1995-96 and 1995-96 to $1998-99$ 


\section{References}

Adriaanse, A., Bryant, D., Hammond, A.L., Rodeburg, E. and Woodward, R. (1995), 'Environmental indicators: a systematic approach to measuring and reporting on environmental policy performance in the context of sustainable development,' Washington D.C., World Resources Institute.

Adriaanse, A. (1993), 'Environmental policy performance indicators: a study of the development of indicators for environmental policy in the Netherlands', The Hague, SDU Publishers.

Agarwal, Bina (1995), 'Gender, Environment and Poverty Interlinks in Rural India: Regional Variations and Temporal Shifts, 1971-1991', Discussion Paper No. 62, Switzerland, United Nations Research Institute for Social Development.

Aldy, J.E. (2004), 'An Environmental Kuznets Curve Analysis of U.S. StateLevel Carbon Dioxide Emissions', Working Paper, Department of Economics, Cambridge, USA, Harvard University.

Andreoni, J. and Levinson, A. (2001), The simple analytics of the Environmental Kuznets Curve', Journal of Public Economics, Vol. 80, No.1, 269-86.

Baldwin, R. (1995), 'Does sustainability require growth?', in Goldin, I. and Winters, L.A. (eds.), 'The Economics of Sustainable Development', Cambridge, UK, Cambridge University Press, pp. 19-47.

Bruvoll, A. and Medin, Hege (2003), 'Factors Behind the Environmental Kuznets Curve: A Decomposition of the Changes in Air Pollution', Environmental and Resource Economics, Vol. 24, No. 1, 27-48. 
Carson, R.T., Jeon, Y. and McCubbin, D.R. (1997), The relationship between air pollution emissions and income: US Data', Environment and Development Economics, Vol. 2, No. 4, 433-50.

Convention on Biological Diversity (CBD): Undated, Global Biodiversity Outlook, Montreal, Quebec, Canada, UNEP, available at http://www.biodiv.org/gbo/annex.asp?ann=1. accessed on 12.02 .2005

Dasgupta, Partha (2001), 'Human Well-Being and the Natural Environment', New Delhi, Oxford University Press.

de Bruyn, S.M., van den Berg, J.C.J.M. and Opschoor, J.B. (1998), 'Economic growth and emissions: reconsidering the empirical basis of environmental Kuznets curve', Ecological Economics, Vol. 25, 161-75.

Dinda, S. (2004), 'Environmental Kuznets Curve Hypothesis: A Survey', Ecological Economics, Vol. 49, 431-55.

EPWRF (2003), 'Domestic Product of State of India: 1960-61 to 2000-01', Database Software.

Esty, D.C., Levy, M., Srebotnjak, T. and de Sherbinin, A. (2005), '2005 Environmental Sustainability Index: Benchmarking National Environmental Stewardship', New Haven, Yale Center for Environmental Law \& Policy.

Garg, Amit and Shukla, P.R. (2002), 'Emission Inventory of India', New Delhi, Tata McGraw-Hill Publishing Company Limited.

Grossman, G.M. and Krueger, A.B. (1995), 'Economic Growth and the Environment', Quarterly Journal of Economics, Vol. 110, 353-78.

Jha, Raghbendra and Bhanu Murthy, K.V. (2001), 'An Inverse Global Environmental Kuznets Curve', Departmental Working Papers: 2001- 
02, Division of Economics, RSPAS, Canberra, Australia, Australian National University.

Jones, L., Fredricksen, L. and Wates, T. (2002), 'Environmental indicators', Fifth Edition, The Fraser Institute, available at http://www.fraserinstitute.ca/shared/readmore.asp?snav $=\mathrm{pb} \quad$ \&id $=314$. accessed on 12.02.2005

Kathuria, Vinish (2004), 'Impact of CNG on Vehicular Pollution in Delhi: A Note', Transportation Research Part D, Vol. 9, 409-17.

Kathuria, Vinish (2002), 'Vehicular Pollution Control in Delhi, India', Transportation Research - Part D, Vol. 7, No. 5, 373-87.

Kothari, Ashish (1996), 'Structural Adjustment vs. India's Environment', Proceedings of the Annual Meetings, Honolulu, Association for Asian Studies.

Nadkarni, M.V. (2000), 'Poverty, Environment, Development: A Many Patterned Nexus', Economic and Political Weekly, April 1, 2000, 1184-90.

Panayatou, T. (1993), 'Empirical tests and policy analysis of environmental degradation at different stages of economic development', World Employment Research Programme, Working Paper No. WP238, Technology and Employment Programme, Geneva, International Labour Office.

Pezzey, J. (1989), 'Economic Analysis of Sustainable Growth and Sustainable Development', Environment Department Working Paper No 15, Washington D. C., The World Bank.

Rogers, Peter, Jalal, Kazi F., Lohani, Bindu N., Owens, Gene M., Yu, ChangChung, Christia, M. and Dufournaud, Jun B. (1997), 'Measuring 
Environmental Quality in Asia', London, U.K., Harvard University Press and ADB.

RIVM/UNEP: undated, 'Global Environment Outlook (GEO-3)', Bilthoven, The Netherlands, National Institute of Public Health and the Environment (RIVM), UNEP, available at http://arch.rivm.nl/env/int/geo/. accessed on 12.02 .2005

Selden, T.M. and Song, D.S. (1994), 'Environmental quality and development: is there a Kuznets curve for air pollution emissions?', Journal of Environmental Economics and Management, Vol. 27, 14762.

Shafik, N. and Bandyopadhyay, S. (1992), 'Economic growth and environmental quality: time-series and cross-country evidence', World Bank Policy Research Working Paper No. WPS 904, Washington D. C., The World Bank.

Stern, D.I. (1998), 'Progress on the Environmental Kuznets Curve', Environment and Development Economics, Vol. 3, 175-98.

World Development Indicator (2004), available at http://www.worldbank.org/data /countrydata/countrydata.html accessed on 20.02.2005.

World Wildlife Fund (WWF) (2002), 'WWF's Living Planet Report 2002', Switzerland, WWF International available at http://www.panda.org/news facts /publications/general/livingplanet//pr02.cfm. accessed on 12.02.2005. 